the displaced head of the femur in a partially paralysed idiot of thirty-one years could be similar to that observed in a young and healthy child, and who would think it fair to draw a comparison between cases so dissimilar, or who would think that "the true position of the head of the femur" could be learnt from such a case except Dr. Bennett? It is impossible to discuss the subject on such grounds. I am, Sir, your obedient servant,

Grosvenor-street, Feb. 14th, 1885. B. E. BRODHURST.

\section{THE DYNAMITE EXPLOSION IN WESTMINSTER} HALL.

To the Editor of THE LANCET.

SIR,- The professional interest attaching to the results of injury by explosives induces me to offer the following facts for your acceptance and publication. It is already well known how terrible were the injuries sustained by the two police constables - Coles and Cox, at present under care in the Westminster Hospital-in the fearless exercise of their duty; and it cannot fail to excite the most general satisfaction that the lives of these brave men should have been spared.

My present purpose is to communicate some details respecting the serious injuries received by Mr. Edwin Green, the civil engineer, whose miraculous escape exceeds all natural expectation; indeed, the shattered condition of his hat and clothes can alone convey any adequate idea of the danger he survived.

At the request of the secretary of the Imperial Union Accident Assurance Company (in which office Mr. Green was insured) I visited him on the 30th ult., at his office in Abingdon-street, Westminster. Mr. Whitney, of Great cumberland-street, had been in professional attendance since the date of the explosion; and, as the report with which I have been courteously favoured by this gentleman is so complete and descriptive, I may be permitted to include it verbatim as under:

"I was called to see Mr. Green, at 24, Abingdon-street, on the afternoon of Saturday, the 24th ult., whither he had been conveyed from Westminster Hall a few minutes previously, directly after the dynamite explosion. Prior to the explosion he was standing close to the spot where it took place, fell, and was taken up in a perfectly unconscious state. He was then removed to Abingdon-street. I found him with partially restored consciousness, but with his mind clouded and bewildered, lying on a bed, with little or no power of movement. There were at this time loss of vision, deafness, and bleeding from the right ear. The entire nervous system had eridently suffered a serious and severe concussion. The skin of the face had a curious appearance, not as if covered with fine dust, but of being absoIutely dyed with dirt. Half the crown of the hat had been blown away by the explosion, and the clothes very much torn. On opening the front of the shirt the chest and epigastric region presented a large grazed and bruised surface marked with blood, as if a violent blow had been struck by some hard body of considerable size. In a few minutes the patient felt sick and vomited a large quantity of dark, clotted blood, mixed with portions of food. These vomits were repeated at intervals of a few minutes, still in considerable quantities, and then followed coughing and spitting of bright-red, frothy blood from the bronchial tubes and lungs. This hæmorrhage was a source of much anxiety, but, by a constant supply of ice and the administration of lead, was gradually subdued. It has not recurred. With the aid of a good constitution, unremitting care, and excellent nursing, he has made gradual and steady progress towards recovery. The disturbed functions are all steadily improving, the damaged visual and locomotive powers being last in the train of recovering organs. But vision, though improring, is yet wholly unfit for practical and professional purposes.

"Feb. 5th, 1885 .

W. A. WHitNey, M.R.C.S.

Mr. Whitney, in a subsequent letter, says: "I was forcibly struck with the apparent power of the lead in arresting the hæmorrhage; and I may add (which I did not mention in the report) that the administration of Easton's syrup from the date of Jan. 31st has been as obviously beneficial in helping to restore the locomotive power and to remove the paralysing effects of the nervous concussion."
In the last report, dated Feb. 14th, I was gratified to hear that "Mr. Green went home on Tuesday last, and is going on capitally."

Further comment by me is unnecessary.

I remain, Sir, yours faithfully, J. Herbert Stowers, M.D.

Finsbury-circus, E.C., Feb. 1885.

\section{THE CASE OF DR. DAVID BRADLEY. To the Editor of THE LANCET.}

SIR,- - I have pleasure in informing you that I have been able to secure 166 signatures, of practitioners resident in Birmingham, to a memorial to be presented to the Home Secretary in favour of a reconsideration of the verdict in Dr. Bradley's case. At the Birmingham Midland Counties Branch of the British Medical Association held last Thursday, the following resolution was proposed by myself, seconded by Dr. E. B. Whitcombe, Superintendent of the Borough Asylum, and unanimously carried:-

"That this meeting having heard a statement of the case of Dr. David Bradley, recently convicted of felonious assault at the Leicester Assizes, desires to express its opinion that the case is eminently one in which a reconsideration of the verdict of the jury is demanded. This opinion is based upon a consideration of the following facts: First, that the complainant has been admittedly the subject of epileptic fits since childhood; secondly, that such persons are specially liable to be subject to erotic delusions during and after a seizure. It is therefore of the utmost importance that the corroborative evidence in such a case should be decisive, whereas in the case of Dr. Bradley it seems to be singularly defective." I am, Sir, yours truly,

The Crescent, Birmingham, Feb. 16th, 1885. LAwson TAIr.

\section{To the Editor of THF LANCET.}

Srr,-Having been at Leicester Assizes in Norember last, and heard the whole of the evidence given in the above case, I shall be glad if you will allow me a small space in your journal to give you the result of some investigations I have made at the house on Whittington Moor, where the offence was alleged to have taken place. I went over there on the 14th inst., accompanied by Mr. Reginald Naylor, an architect of this town, who has kindly taken a plan of the rooms, which can be produced at any future inrestigation if necessary. The house is situated about the centre of a terrace of small dwellings, and has its front entrance opening direct into a parlour, which is $12 \mathrm{ft}$. square, and has a low bay window. This room was used by Dr. Bradley as a branch surgery, and here it is alleged the offence was committed. It is divided from the kitchen by a space of $2 \mathrm{ft} .8 \mathrm{in}$, containing the staircase. Between the parlour and kitchen are two badly fitting $1 \frac{1}{2}$ in. doors, with panels about sin. thick. With both of these doors fastened we were able to hear conversation going on in the kitchen, and also the rattling of knives and forks whilst the inmates were at dinner. The parlour is separated from the cellar beneath by a plain one-inch boarded floor resting on joists, and conversation going on in the parlour could be distinctly heard in the cellar. During the whole of the time that Dr. Bradley and the prosecutrix were in the parlour together the woman who occupied the house was either in the kitchen or cellar, and yet she heard none of the screaming. The woman's husband was ill in bed in the room immediately over the parlour, where the voices of anyone in ordinary conversation can be distinctly heard, and yet he heard no screaming. Two women were about three yards from the front door, which was proved at the trial to be about one foot open, and yet they heard no sound. With the front door shut I was able to hear distinctly a child across the street playing with a shuttlecock and battledore. The architect admitted that he never saw such flimsily-built houses, and that any screaming must have been heard in the houses on either side, in the cellar below, and the bedroom above the parlour.

In conclusion, allow me to say that I know nothing of Dr. Bradley, and never saw him until he was in the dock.

Friar Gate, Derby, Feb. 1885 . GIr, GoRGE RICE, M.R.C.S. I am, Sir, yours faithfully, 